DOI 10.18551/rjoas.2021-06.18

\title{
HUMOR SENSITIVITY, SOCIAL SUPPORT AND EMOTIONAL AWARENESS OF ACADEMIC RESILIENCE
}

\author{
Suhesty Aulia*, Yuliasari Veranda, Kamaruddin Dewi Febriyani, \\ Mubarak Almar'atul Afuwwah Q.A. \\ Department of Psychology, Mulawarman University, Indonesia \\ *E-mail: aulia.suhesty@fisip.unmul.ac.id
}

\begin{abstract}
This study aims to determine the effect of humor sensitivity, social support, and emotional awareness on students' academic resilience of the Faculty of Forestry, Mulawarman University. This study used a quantitative approach with 120 students of the Faculty of Forestry, Mulawarman University, selected using a simple random sampling technique. Data collection methods used are humor sensitivity scale, social support, emotional awareness, and academic resilience. The collected data were analyzed using the Statistical Package for Social Science (SPSS) 25.0 for Windows program. These results indicate a significant influence between sensitivity, humor, social support, and emotional awareness of academic resilience with a value amounting to 33435 and pF for 0000 that has a valuable contribution of influence $\left(R^{2)}\right.$ of 46.4 percent. There is a positive and significant influence between humor sensitivity on academic resilience with a beta value of 0.356 , $t$ count of 3.292 , and $p$ of 0.001 . There is no significant influence between social support for academic strength with a beta value of 0.140 , $t$ count of 1.303 , and $p$ of 0.195 . There is a positive and significant influence between emotional awareness on academic resilience with a beta value of 0.285 , t count of 3.347 , and $p$ of 0.001 .
\end{abstract}

\section{KEY WORDS}

Social support, humor sensitivity, emotional awareness, academic resilience.

Hartaji (2012) argues that students refer to people in the learning process and have registered for education at a college. During their studies in tertiary institutions, students are responsible academically as a generation capable of managing and developing resources with the academic provisions after graduating. Students have a lot of responsibilities and tasks in lectures that they have to complete. However, many students cannot hold on to this pressing responsibility, so that students become vulnerable to negative emotions and often do not think long enough, causing stress.

Research to determine the level of stress experienced by students has been carried out at several universities globally. According to Habeeb (2010), the total number of students globally who experience stress is 38-71\%, while the total number of students in Asia is 39.6$61.3 \%$. Meanwhile, the total number of students who experience stress in Indonesia is 36.7 $71.6 \%$ (Fitasari, 2011). This can explain that students can experience stress due to the demands of academic assignments they receive.

Each student raises a different response to problems and obstacles in his lecture. Therefore, academic adaptation ability is needed to survive that students must have in their studies. This academic adaptability is referred to as academic resilience (Gwyther, Resnick, and Roberto (2011). Academic resilience is an individual's ability to adapt and bounce back from difficult circumstances so that individuals can restore their situation and recover their psychological condition as quickly as before. Academic activities are undertaken. By being resilient, students will withstand pressure or difficulties and not show negative emotions continuously.

According to Taormina (2015), there are four aspects of academic resilience, namely determination, including determination and firmness on specific goals, resilience includes resilience to withstand unpleasant feelings, adaptability includes the ability to be flexible and 
adjust according to circumstances, and self-recovery includes the ability to recover and return as usual from unpleasant events.

Du, Huang, An, and Xu (2018) explain that if an individual feels depressed, it raises negative thoughts and emotions. It will have the potential to cause stress, anger, anxiety, or depression to increase. The students' sensitivity to humor can be a problem-solving to survive unpleasant situations in their lecturing activities. Kuiper (2012) stated that someone who has a high sense of humor shows the resulting influence on positive emotions, hard work, and high motivation to solve the problem. The positive emotions present through humor are a form of problem-solving that provides a source of meaning in interpreting students' life experiences.

In addition to being able to process positive emotions, resilient students can get positive emotions when they are with other people to produce a context of social support that helps solve problems in lectures. Martin and Ford (2018) stated that social context is an activity that supports individual academic resilience by using humor so that individuals will often laugh and joke when they are with other people.

Social support is a relationship; when someone faces a problem or obstacle, this relationship assists in the information or practical assistance to feel cared for and loved (Handono \& Bashori, 2013). Social support is beneficial for students in improving and maintaining psychological, physical well-being, reducing stress levels, feeling accepted in the lecture environment, increasing self-confidence, and generating positive emotions to help students solve problems that come in their lectures, including having the ability to have academic resilience.

A student must understand, realize, and express the emotions present in them, which is known as emotional awareness. Kesadaran's emotional is the expertise of individuals in recognizing and describing her emotional state (Versluis et al., 2018). The experiences that students experience become a source in realizing and differentiating the present emotions in students. Students must be able to manage these emotions to adapt and survive unpleasant circumstances during their lecture activities.

According to Gwyther, Resnick, and Roberto (2011), factors that can affect academic resilience in individuals are four, namely self-esteem or a sense of trust in an individual's abilities, social support or social support provided by other individuals, spirituality, namely individual trust. To God, and finally, the positive emotions that individuals have been able to help them survive difficult circumstances during academic activities. Therefore, students who have more positive emotions and are aware will be more resistant to complicated lectures.

Researchers see that the student life of the Faculty of Forestry is not easy. They are faced with assignments, field practicum, and practicum reports with a fast collection schedule. The academic burdens received by the Faculty of Forestry students can trigger stress if they are not able to solve these problems, so that students of the Faculty of Forestry need good academic resilience.

Researchers are interested in knowing the effect of humor sensitivity, social support, and emotional awareness on academic resilience in students of the Faculty of Forestry, Mulawarman University. In this study, the hypothesis is that first, there is an effect of humor sensitivity, social support, and emotional awareness on academic resilience. Second, the effect of humor sensitivity on academic resilience. Third, the effect of social support on academic resilience. Fourth, the effect of emotional awareness on academic resilience.

\section{METHODS OF RESEARCH}

The method used in this research is quantitative. The dependent variable is academic resilience, and the independent variables are humorous sensitivity, social support, and emotional awareness. The total population was 1,327 students of the Faculty of Forestry, Mulawarman University. The sampling technique used in this study is the simple random sampling technique; the use of this technique is because the determination of the sample from the population is done randomly without paying attention to the strata in the population 
(Sugiyono, 2017). This study used the test technique try out for students of the Faculty of Forestry, Mulawarman University, with as many as 120 members.

In contrast, the reason for using the try-out was used due to time constraints. The test is carried out to obtain the accuracy and accuracy of the measuring instrument in performing its measuring function. Data obtained through a scaling instrument with a Likert scale type on the four variables, namely academic resilience, humor sensitivity, social support, and emotional awareness. The scale has been tested to determine the level of validity and reliability results on each scale showing the value of Cronbach's alpha $\geq 0.600$. According to Azwar (2016), the measurement results can be reliable if they value Cronbach's Alpha of at least 0.600 . Data analysis for research data processing uses multiple regression analysis to determine how much influence and predictive ability of the three independent variables (humor sensitivity, social support, and emotional awareness) on the dependent variable (academic resilience).

\section{RESULTS OF STUDY}

Descriptive data were used to determine the condition of data distribution among students of the Faculty of Forestry, Mulawarman University. The empirical and mean were hypothetically obtained from the response of the research sample through four research scales, namely the academic resilience scale, humor sensitivity, social support, and emotional awareness.

Table 1 - Mean Empirical and Mean hypothetical

\begin{tabular}{llll}
\hline Variable & Mean Empirical & Mean hypothetical & Status \\
\hline Y & 151.79 & 114 & High \\
X1 & 130.26 & 96 & High \\
X2 & 170.84 & 132 & High \\
X3 & 160.80 & 138 & High \\
\hline
\end{tabular}

In the table above, the data distribution is generally known research on Mulawarman University Faculty of Forestry. Based on the measurement results on the academic resilience scale, the mean of empirical151.79 is higher than the mean hypothetical114 in the high category. Based on the measurement results on the humor sensitivity scale, the mean was empirical130.26 higher than the mean hypothetical96 in the high category. Based on the measurement results on the social support scale, the mean of empirical170.84 is higher than the mean of hypothetical132 in the high category.

Based on the measurement results on the emotional awareness scale, the mean empirical160.80 is higher than the mean hypothetical138 with the high category. Before analyzing the data in hypothesis testing, it is necessary to do an assumption test consisting of a normality test and a linearity test.

The data normality test, among others, can be done by comparing the probability of the Kolmogorov-Smirnov value with $0.05(5 \%)$. The rule used is if $p>0.05$, then the distribution is average; on the other hand, if $p<0.05$, the distribution is not normal (Santoso, 2012). The results of the normality test can be seen in the table below.

Table 2 - Results of the Normality Test

\begin{tabular}{llll}
\hline Variable & Kolmogorov-Smirnov & $\mathrm{P}$ & Subject \\
\hline Y & 0.092 & 0.015 & 120 \\
X1 & 0.070 & 0.200 & 120 \\
X2 & 0.045 & 0.200 & 120 \\
X3 & 0.080 & 0.057 & 120 \\
\hline
\end{tabular}

The linearity test is if the value of deviation from linearity is $p>0.05$ and the value of $F$ count $<\mathrm{F}$ table at a significance level of $5 \%$ or 0.05 , then the relationship is declared linear (Sudarmanto, 2013). The following test results linearity between each independent variable and the dependent variable are presented in the table below: 
Table 3 - Linearity Test Results

\begin{tabular}{llll}
\hline Variable & & Value & \\
\cline { 3 - 4 } & & $\mathrm{F}$ & $\mathrm{P}$ \\
\hline $\mathrm{Y}$ & $\mathrm{X} 1$ & 1.408 & 0.094 \\
& $\mathrm{X} 2$ & 1.204 & 0.241 \\
& $\mathrm{X} 3$ & 1.161 & 0.282 \\
\hline
\end{tabular}

Based on the results in the table above shows that inter variables have a linear relationship ( $p>0.05)$.

Hypothesis testing in this study was to determine the effect of humor sensitivity, social support, and emotional awareness on academic resilience in students of the Faculty of Forestry, Mulawarman University. The analysis technique used is multiple linear regression analysis. The results of the regression analysis are as follows.

Table 4 - Results of Regression Analysis

\begin{tabular}{lllll}
\hline Variable & F Count & F Table & $\mathrm{R}^{2}$ & $\mathrm{P}$ \\
\hline $\mathrm{Y}$ & & & & \\
$\mathrm{X} 1$ & 33.435 & 2.68 & 0.464 & 0.000 \\
$\mathrm{X} 2$ & & & \\
$\mathrm{X} 3$ & & & \\
\hline
\end{tabular}

Based on the above results, the $F$ count> $F$ table shows that humor sensitivity, social support, and emotional awareness of academic resilience significantly influence a value of $F$ $=33435, R^{2}=0.464$, and $p=0.000$. This means that the significant hypothesis in this study is accepted. Furthermore, to test the multiple linear regression hypotheses to determine the relationship in a stimulant manner, multiple linear regression analysis results are as follows.

Table 5 - Results of Multiple Linear Regression Analysis

\begin{tabular}{llllll}
\hline Variable & & Beta & T Calculate & T Table & $\mathrm{P}$ \\
\hline \multirow{3}{*}{$\mathrm{Y}$} & $\mathrm{X} 1$ & 0.356 & 3.292 & 1.980 & 0.001 \\
& $\mathrm{X} 2$ & 0.140 & 1.303 & 1.980 & 0.195 \\
& $\mathrm{X} 3$ & 0.285 & 3.347 & 1.980 & 0.001 \\
\hline
\end{tabular}

Based on the table above, $t$ count $>t$ table which means that there is a significant influence between humor sensitivity towards academic resilience with a beta value $=0.356$, t count $=3.292$, and $p=0.001(p<0.05)$. Then the social support for academic resilience shows $t$ count $<\mathrm{t}$ table, which means that there is no significant effect with the beta value $=0.140$, t count $=1.303$, and $p=0.195(p>0.05)$. Furthermore, emotional awareness of academic resilience shows $t$ count $>t$ table which means that there is a significant influence with the beta value $=0.285$, t count $=3.347$, and $p=0.001(p<0.05)$.

\section{DISCUSSION OF RESULTS}

This research was conducted to determine humor sensitivity, social support, and emotional awareness on students' academic resilience of the Faculty of Forestry, Mulawarman University class of 2017-2019. In the first hypothesis based on the full regression model analysis results, the results obtained were the value of $F=33,435$ and the value of $p=0.000$ ( $p<0.05$ ). This means that the significant hypothesis is accepted, which means the sensitivity of humor, social support, and emotional awareness to the resilience of the academic has significant influence with the contribution of influence $\left(R^{2)}\right.$ sensitivity humor, social support, and emotional awareness there is the resilience of academic amounted to 0.464 , (46.4 percent) of the variation in academic resilience can be explained by humorous sensitivity, social support, and emotional awareness. At the same time, the remaining 53.6 percent explained by other variables or other reasons not examined in this study. 
In line with the factors that influence academic resilience, according to Gwyther, Resnick, and Roberto (2011) that there are four factors, namely self-esteem, social support, spirituality, and positive emotions. The factors in this study include factors self-esteem that capabilities are problem-solving using humor sensitivity, social support, and positive emotions realized by one-self or called emotional awareness.

Students tend to solve problems that generate positive feelings that make themselves and others feel happy through stories or something funny, then generate smiling or laughing responses. Positive emotions that exist through the sensitivity of humor and social support received by students are one of the factors that shape student academic resilience, as explained by Gwyther, Resnick, and Roberto (2011). Therefore, a student must understand and be aware of their emotions based on their emotional experiences; this is called emotional awareness. They are finally able to manage these emotions during their lecture activities and foster student academic resilience.

The second hypothesis, based on the stepwise regression model analysis results, shows that the sensitivity of humor to students' academic resilience of the Faculty of Forestry, Mulawarman University, shows a significant effect. The value of beta $=0.356$, t count $=3.292$, and $p=0.001(p<0.05)$, which means that the higher the humor sensitivity of the students, the higher the academic resilience of students, if the lower the sensitivity. The humor the students have, the lower the academic resilience of the students.

The above is in line with the results of research conducted by Wardhana (2018) that there is an influence of humor sensitivity on academic resilience in final undergraduate students at Airlangga University. His research shows that the higher the humor sensitivity of students, the better academic resilience will be, especially in coping with humor. Sensitivity to humor can improve the psychological health of students when they are in trouble or obstacles because humor helps improve mental states to be positive in facing all obstacles by smiling and laughing (Pande, 2014).

The third hypothesis is based on the results of the stepwise regression model analysis test. Social support for students' academic resilience of the Faculty of Forestry, Mulawarman University, shows no significant effect. This is evidenced by the value of beta $=0.140, t$ count $=1.303$, and $p=0.195(p>0.05)$. This means that social support is not one of the causes that make students have academic resilience.

This is by the research results conducted by Maria (2017) on 49 students majoring in Medical Education at UIN Maulana Malik Ibrahim Malang. It is known that social support does not have a significant effect on the academic resilience of students. His research shows that students still feel gaps with other people, both friends, and teachers. This gap dominates the condition of students so that it is challenging to face difficulties in lectures. Social support is a relationship; when someone faces a problem or obstacle, this relationship assists in the information or practical assistance to feel cared for and loved (Handono \& Bashori, 2013).

Then in the fourth hypothesis, based on the results of the stepwise regression model analysis hypothesis. Emotional awareness of students' academic resilience of the Faculty of Forestry, Mulawarman University shows that there is a significant effect. This is evidenced by the value of beta $=0.285$, t count $=3.347$, and $p=0.001(p<0.05)$. It can be interpreted that the higher the emotional awareness of students, the higher the academic resilience of students. This also applies to the opposite; if the lower the emotional awareness of students, the lower students' academic resilience.

In this study, it is known that the characteristics of respondents are dominated by members of the female gender (59.2 percent), aged between 17 and 19 years (49.2 percent), and are students of class 2019 (45 percent). This is in line with the opinion expressed by Mankus, Boden, and Thompson (2016) that the factors that affect a person's emotional awareness are age and gender. As they get old, students will have more experiences and opportunities to identify, classify, and express their emotions. Then female students also tend to be more able to express their emotions and are more able to regulate their emotions than men. The emotional experiences they have are what help students understand and become aware of the emotions they feel. 
Based on the results of the descriptive test, it can be seen that the description of the distribution of data on research subjects, in general, is on students of the Faculty of Forestry, Mulawarman University. On a scale of academic resilience with a value $>152, f=61$ (50.3 percent). Humor sensitivity scale with a value $>128, f=63$ (52.5 percent). Social support scale with a value between 147-176, $f=50$ (41.7 percent). Then on the emotional awareness scale with a value between $153-184, f=79$ (65.8 percent). This shows that students of the Faculty of Forestry, Mulawarman University, have high academic resilience, humorous sensitivity, social support, and emotional awareness.

Based on the description above, it can be concluded that humor sensitivity and emotional awareness significantly affect academic resilience. In contrast, social support does not significantly affect students' academic resilience of the Faculty of Forestry, Mulawarman University. This is because other factors influence academic resilience, one of which is social adaptability. When students have social adaptability, it tends to increase academic resilience.

\section{CONCLUSION}

Based on the results of the research that has been done, it can be concluded that there is a significant influence between humor sensitivity, social support, and emotional awareness on academic resilience in students of the Faculty of Forestry, Mulawarman University, with an $\mathrm{F}$ value of $33,435(\mathrm{p}<0.05)$. There is an influence of humor sensitivity on academic resilience in students of the Faculty of Forestry, Mulawarman University. The $t$ value is 3.292 ( $p<0.05)$. There is no influence of social support on academic resilience in students of the Faculty of Forestry, Mulawarman University. The t value is 1.303 ( $p>0.05$ ). There is an effect of emotional awareness on academic resilience in students of the Faculty of Forestry, Mulawarman University. The $t$ value is $3,347(p<0.05)$. The practical contribution of humor sensitivity, social support, and emotional awareness to predict academic resilience in students of the Faculty of Forestry, Mulawarman University, was $46.4 \%$. In comparison, the remaining $53.6 \%$ was influenced by other factors not examined in this study.

It is hoped that students can maintain and increase their sensitivity to humor, social support from loved ones, and emotional awareness to increase their academic resilience in themselves. It is hoped that students who have academic responsibilities in order to be able to build the nation with the academic provisions they have after graduating must have academic resilience in them so that they can withstand the stressful conditions in lectures. This can be done by increasing sensitivity to humor, social support from loved ones, and emotional awareness in students. It is hoped that the following researchers interested in academic resilience should study more broadly the factors that can affect academic resilience considering that in the results of this study, there are variables that do not affect academic resilience, namely social support variables. So that further researchers are expected to find even better findings from the results of previous studies.

\section{REFERENCES}

1. Azwar, S. (2016). Konstruksi tes kemampuan kognitif. Yogyakarta: Pustaka Pelajar.

2. Du, J., Huang, J., An, Y., \& Xu, W. (2018). The relationship between stress and negative emotion: The mediating role of rumination. Clin Res, 4(1), 1-5.

3. Fitasari, I. N. (2011). Faktor yang berhubungan dengan kejadian stres pada mahasiswa fakultas kesehatan masyarakat universitas airlangga. Surabaya: Universitas Airlangga.

4. Gwyther, L. P., Resnick, B., \& Roberto, K. A. (2011). Resilience in aging: Concepts, research, and outcomes. Springer.

5. Habeeb, K. A. (2010). Prevalence of stressors among female medical students taibah university. Journal of Taibah University Medical Sciences, 5(2), 110-119.

6. Handono, O. T., \& Bashori, K. (2013). Hubungan antara penyesuaian diri dan dukungan sosial terhadap stres lingkungan pada santri baru. Empathy, 1(2), 79-89. 
7. Hartaji, D. A. (2012). Motivasi berprestasi pada mahasiswa yang berkuliah dengan jurusan pilihan orangtua. Fakultas Psikologi Universitas Gunadarma.

8. Kuiper, N. A. (2012). Humor and resiliency: Towards a process model of coping and growth. Europe's Journal of Psychology, 8(3), 475-491.

9. Mankus, A. M., Boden, M. T., \& Thompson, R. J. (2016). Sources of variation in emotional awareness: Age, gender, and socioeconomic status. Personality and Individual Differences, 89, 28-33.

10. Maria, H. (2017). Pengaruh determinasi diri dan dukungan sosial terhadap resiliensi akademik pada mahasiswa jurusan pendidikan dokter di UIN Maulana Malik Ibrahim Malang. Malang: UIN Maulana Malik Ibrahim.

11. Martin, R. A., \& Ford, T. (2018). The psychology of humor: An integrative approach. Academic Press.

12. Pande, N. (2014). Effect of sense of humour on positive capacities: An empirical inquiry into psychological aspects. Global Journal of Finance and Management, 6(4), 385-390.

13. Santoso, S. (2012). Aplikasi SPSS pada statistik parametrik. Jakarta: PT Elex Media Komputindo.

14. Sudarmanto, R. G. (2013). Statistik terapan berbasis komputer dengan program IBM SPSS statistik 19. Jakarta: Mitra Wacana Media.

15. Sugiyono. (2017). Metode Penelitian Kuantitatif, Kualitatif dan R\&D. Bandung: Alfabeta, CV.

16. Taormina, R. J. (2015). Adult personal resilience: A new theory, new measure, and practical implications. Psychological Thought, 8(1), 35-46.

17. Versluis, A., Verkuil, B., Lane, R. D., Hagemann, D., Thayer, J. F., \& Brosschot, J. F. (2018). Ecological momentary assessment of emotional awareness: Preliminary evaluation of psychometric properties. Current Psychology, 1-9.

18. Wardhana, Y. W. (2018). Pengaruh sense of humor terhadap resiliensi akademik mahasiswa akhir masa studi sarjana di universitas airlangga. Surabaya: Universitas Airlangga. 